\title{
STRATEGI PENGEMBANGAN PENDIDIKAN MULTIKULTURAL DI JAWA BARAT
}

\author{
Hisny Fajrussalam ${ }^{1}$, Uus Ruswandi ${ }^{2}$, Mohamad Erihadiana ${ }^{3}$ \\ UPI $^{1}$, UIN Sunan Gunung Djati, Bandung Indonesia ${ }^{2,3}$ \\ hfajrussalam@upi.edu; uusruswandi@uinsgd.ac.id; \\ erihadiana@uinsgd.ac.id.
}

\begin{abstract}
ABSTRAK
Penelitian dilatabelakangi oleh keragaman etinik, suku bangsa, bahasa, warna kulit, agama, dan status sosial masyarakat di Jawa Barat yang berpotensi terjadinya konflik horizontal apabila tidak dibekali dengan pendidikan multikultural. Penelitian ini menggunakan pendekatan kualitatif dengan metode studi kepustaan dan teknik konten analisis. Data yang diperoleh dikompulasi, dianalisis dan disimpulkan. Hasil penelitian menunjukan bahwa pendidikan multikultural memiliki peran penting dalam rangka menumbuhkan sikap saling menghargai, tidak mudah curiga, dan membangkitkan semangat untuk menjaga keutuhan NKRI. Walaupun penelitian mengenai pendidikan multikultural sudah banyak dilakukan, namun kenyataannya model pendidikan seperti ini belum dapat direalisasikan secara utuh dalam jiwa masyarakat Jawa Barat. Oleh karenanya, diperlukan adanya strategi pengembangan pendidikan multikultural untuk menjaga keharmonisan masyarakat di Jawa Barat serta menumbuhkan sikap pluralisme dan menghargai perbedaan. Strategi pengembangan yang dapat dilakukan adalah brainstorming (tukar gagasan) dan pelaksanaan kegiatan, baik yang bersifat wacana (seperti seminar, lokakarya, dan talk show), maupun yang bersifat praktis (seperti riset, penyusunan modul, penyusunan kurikulum baru, pembuatan buku, pelatihan-pelatihan, simulasi, kampanye media dan lainnya).
\end{abstract}

\section{Kata Kunci: Strategi, Pendidikan Multikultural, Pengembangan}

\begin{abstract}
The research is motivated by the diversity of ethics, ethnicity, language, skin color, religion, and social status of the people in West Java which has the potential for horizontal conflicts if not equipped with multicultural education.This study uses a qualitative analysis with library research methods and content analysis techniques. The data obtained is compiled, analyzed and concluded. The results showed that multicultural education has an important role in the framework of fostering mutual support, not being suspicious, and encouraging the spirit to maintain the integrity of the Unitary Republic of Indonesia. Although research on multicultural education has been done a lot, supporting this educational model cannot be fully realized in the soul of the people of West Java. Therefore, there is a need for a multicultural education development strategy to demand harmony in the community in West Java and also foster pluralism and respect for differences. Development strategies that can be carried out are brainstorming (instead of leadership) and implementation of activities, both those that oppose discourse (such as seminars, training, and talk
\end{abstract}

Jurnal Edueksos Vol. IX, No. 1, Juni 2020

The journal of social and economics education 
shows), and also practical ones (such as research, module settings, new curriculum connections, bookmaking, training, simulations, media campaigns, and others).

\section{Keywords: Development, Multicultural Education, Strategy}

\section{A. PENDAHULUAN}

Sekitar satu abad lalu, Jawa Barat sudah ditakdirkan sebagai provinsi yang memiliki keragaman etnik. Tabroni mencatat, kelahiran Bandung (yang kemudian menjadi Ibu Kota Jawa Barat) tempo dulu tidak lepas dari keragaman etnik dan suku bangsa. Bahkan menurutnya, penetapan Bandung sebagai Ibu Kota Jawa Barat didasarkan pada pertimbangan pemerintah Kolonial yang ingin memanjakan bangsa Eropa yang saat itu tinggal di Bandung. Tahun 1990 saja, bangsa Eropa yang ada di Bandung mencapai 1.522 orang, terdiri dari para pejabat dan pengusaha. Jumlah itu terus meningkat dari tahun ke tahun (Tabroni, 2007).

Begitupun dalam perjalanannya, Jawa Barat selalu menjadi tempat yang memiliki daya tarik tersendiri bagi masyarakat lain, baik dalam negeri maupun mancanegara. Tidak aneh jika Jawa Barat kemudian menjadi provinsi terbanyak penduduknya di Indonesia. Dari sensus penduduk terakhir yang dapat kita lihat dari data Badan Pusat Statistika (BPS) Jawa Barat, di tahun 2010 kita dapat melihat lonjakan penduduk Jawa Barat yang mencapai 43.053.732 jiwa. Dari jumlah sebanyak itu, 11.410 jiwa di antaranya warga asing (Badan Pusat Statistika Jawa Barat, Data Sensus Penduduk tahun terkahir, 2010), hingga tahun 2019 jumlah penduduk Jawa Barat mencapai 49.316.712 jiwa.

Pada sisi agama, keberagaman dapat dilihat dari jumlah tempat ibadah dan jumlah pemeluknya. Tempat ibadah umat Islam (sebagai pemeluk agama mayoritas) sebanyak 81.194 buah. Jumlah ini terdiri dari 45.164 Masjid dan 36.030 Musholla. Selain itu di Jawa Barat juga terdapat 406 Gereja Kristen, 51 Gereja Katolik, 28 Pura Hindu, 196 Vihara Budha, dan 30 Klenteng Konghucu (Kemenag Jabar, 2019).

Pada waktu-waktu tertentu, Jawa Barat juga senatiasa kebanjiran manusia yang berlainan etnik, suku bangsa, Bahasa, dan agama. Hal ini dapat dilihat dari besarnya jumlah wisatawan macanegara yang berkunjung ke Jawa Barat berikut ini: 


\section{Jumlah Wisatawan Mancanegara yang Berkunjung ke Jawa Barat Rentang Tahun 2016-2019}

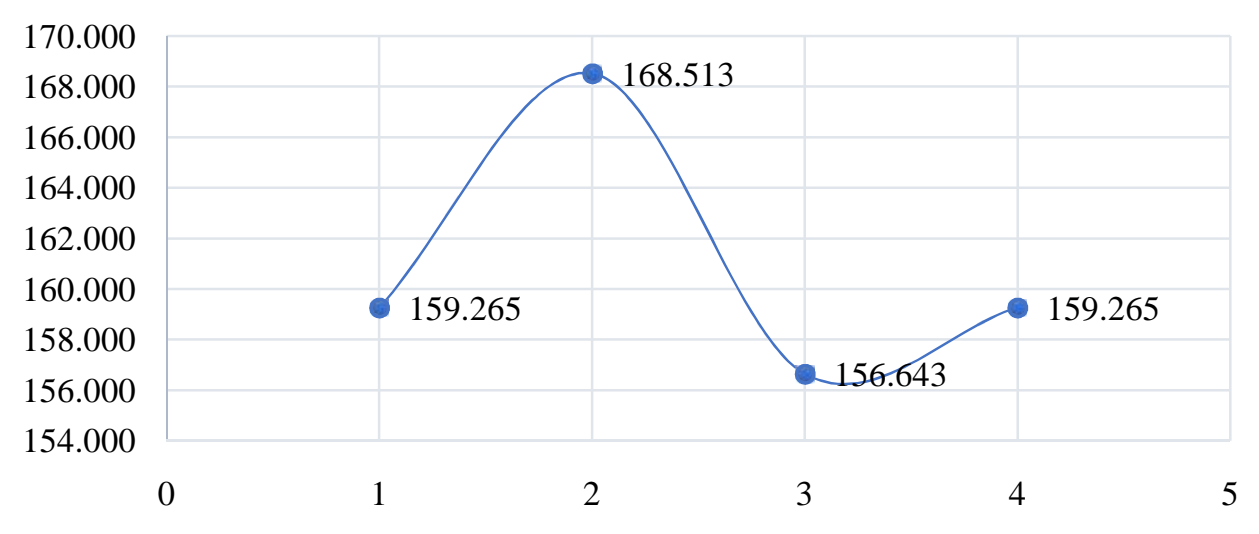

\section{Gambar 1.Jumlah Wisatawan Mancanegara yang Berkunjung ke Jawa Barat Rentang Tahun 2016-2019}

(Sumber: Badan Pusat Statistika Jawa Barat)

Dari data di atas kita dapat melihat bahwa ada penurunan jumlah wisatawan mancanegara yang berkunjung ke Jawa Barat pada tahun 2018, akan tetapi jumlahnya naik kembali di tahun 2019. Dari sini kita dapat menyebutkan bahwa Jawa Barat memang menawarkan pesona alam yang ramah dan menawan bagi siapapun yang ingin menikmatinya, tidak terkecuali orang asing. Akan tetapi kehadiran jumlah wisatawan yang besar ini bukan tanpa resiko. Hadirnya wisatawan mancanegara berpotensi menimbulkan disintegrasi sosial jika tidak dibekali dengan pendidikan multikultural (Ruastati, 2010).

Fenomena Jawa Barat adalah fenomena keragaman etinik, suku bangsa, Bahasa, warna kulit, agama, dan status sosial. Di Jawa Barat ini kita akan menemukan keragaman yang belum tentu ditemukan di provinsi lain. Jawa Barat memang laksana bumi yang mengkerut.

Apakah sampai di sini keragaman kultur itu terjadi? Ternyata tidak, dan bahkan ke depan, dunia sedang dilanda demam Era Industri 4.0. Jawa Barat sebagai bagian dari bangsa Indonesia juga merupakan daerah yang terbuka, paling dekat ke Ibu Kota Negara, akan menjadi salah satu tempat paling strategis untuk melakukan aktivitas bisnis, pendidikan, dan yang lainnya. Konsekuensinya, Jawa Barat akan menjadi provinsi yang mendapat imbas migrasi kultural yang sangat dahsyat. 
Dengan bergumulnya keragaman etnik dalam suatu wilayah yang relatif sempit, sangat dimungkinkan terjadinya sentiment-sentimen kesukuan, kedaerahan atau agama. Oleh karena itu,berbagai pertimbangan yang mendalam dan hati-hati pada tingkat filosofis, strategis maupun praktis haruslah dilakukan oleh setiap unsur budayan dan etnis dalam upaya untuk menghindari berbagai konflik kultural di masyarakat.

Sebuah masyarakat Jawa Barat yang beragam seperti Jawa Barat kata harus menghindari sifat-sifat ekstrimis, eksploitatif, diskriminatif dari kaum mayoritas atau kuat terhadap masyarakat minoritas atau lemah dan sebaliknya. Berbagai konflik antarsuku, budaya, ras, dan agama yang sering terjadi di masyarakat disebabkan sentiment kesukuan, ras, kedaerahan, dan agama yang berlebihan juga ditekan pada titik yang paling ekstrim.

\section{B. METODE PENELITIAN}

Pendekatan yang digunakan dalam penelitian ini adalah pendekatan kualitatif. Teknik analisis yang digunakan adalah konten analisis.Jenis data yaitu berupa data sekunder. Penelitian dilakukan dengan mengindentifikasi masalah yang terjadi di Jawa Barat mengenai potret multikulturalisme dengan mengambil data dari Badan Pusat Statistika Provinsi Jawa Barat Tahun 2016-2020 dan Kementerian Agama Provinsi Jawa Barat kemudian dikompulasi, dianalisis, dan disimpulkan kebutuhan yang mungkin dapat menjadi penyelesaian masalah tersebut berupa strategi pengembangan dengan menggunakan studi kepustakaan.

\section{HASIL DAN PEMBAHASAN}

\section{Teologi Multikultural: Suatu Pendekatan}

Dalam menghindari situasi konflik komunal yang terjadi di masyarakat, Islam merasa perlu mendefinisikan kehadirannya dalam konteks keragaman agama dan budaya, sekaligus menawarkan suatu harapan dan perspektif keagamaan baru bahwa Islam adalah seraut wajah tersenyum (smiling face of Indonesian Moeslim), damai dan nir-kekerasan. Karenanya, Islam perlu memberikan nuansa paradigmatik bagi rekontruksi dan pembangunan karakter bangsa pada umumnya (Baidhawi, 2002). Ia perlu membangkitkan kembali idealisasi sebagai agama non-sentralistik, kebalikan dari sifat indoktriner dan otoriter. Tanpa mengabaikan ajaran-ajaran teologis yang dipahami untuk memperkuat keimanan dan pencapaian nilai-nilai 
eskatologis, Islam mengiringinya dengan kesadaran berdialog dan kesiapan untuk berjumpa dengan siapa pun, kapan pun dan dimana pun dikehendaki. Dengan cara ini, Islam mempunyai kesempatan untuk tampil sebagai agama publik sekaligus agama profetik yang menjanjikan dengan perspektif khas multikulturalis.

Dalam kegagalan politik penguasa mengelola masyarakat multikultural, paradigma moral dan etis Islam multikultural sudah saatnya menjadi sumber kehidupan berbangsa dan bernegara. Islam multikultural adalah sebentuk perspektif teologis tentang penghargaan terhadap keragaman; suatu assessment teologis mengenai agama lain, kultur lain, dan etnik lain serta penempatannya secara layak dalam wilayah tatanan publik; sebagai teologi qur'ani yang membolehkan "sang lian" menjadi "yang lain" sebagai realitas yang secara etis diperkenankan bahkan merupakan sebuah keniscayaan. Inilah perspektif teologis abad 21 yang berkomunikasi melampaui Bahasa dan tradisi partikular.

Menurut Baidhawi (2002), meminjam istilah Abdulaziz Sachedina, ini merupakan "sensibilitas akumene" (ecumenical sensibility) dari teologi multikultural yang menggambarkan perhatian dan kepedulian mereka melampaui batas-batas komunitas keagamaan dan kultural. Tujuan luhur teologi multikulturalis adalah pembebasan dari belenggu kebodohan, kemiskinan, keterbelakangan, kezaliman, dan ketidakadilan sebagai akibat dari relasi kolonial atas-bawah, dominasi-subordinasi, superior-inferior, menindas-tertindas, baik dalam hubungan antaragama, antaretnik, dan antar budaya.

Atas dasar adanya pengakuan mengenai pluralism budaya dan agama, maka Al-Qur'an secara tegas konsep perlombaan dalam kebaikan dalam QS.Al-Baqarah ayat 148 dan QS. Al-Maidah ayat 48:

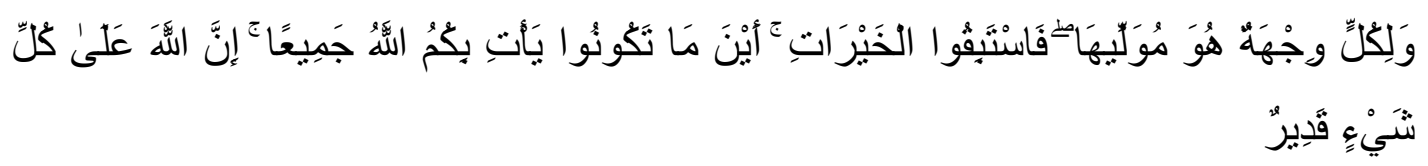

"Dan bagi tiap-tiap umat ada kiblatnya (sendiri) yang ia menghadap kepadanya.Maka berlomba-lombalah (dalam membuat) kebaikan. Di mana saja kamu berada pasti Allah akan mengumpulkan kamu sekalian (pada hari kiamat). Sesungguhnya Allah Maha Kuasa atas segala sesuatu." 


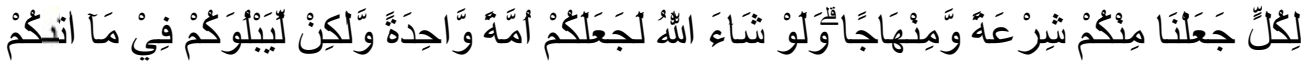

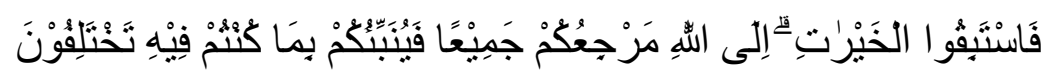

"Untuk setiap umat di antara kamu, Kami berikan aturan dan jalan yang terang.Kalau Allah menghendaki, niscaya kamu dijadikan-Nya satu umat (saja), tetapi Allah hendak menguji kamu terhadap karunia yang telah diberikan-Nya kepadamu, maka berlomba-lombalah berbuat kebajikan.Hanya kepada Allah kamu semua kembali, lalu diberitahukanNya kepadamu terhadap apa yang dahulu kamu perselisihkan."

Kedua ayat di atas sesuai dengan konsep multikulturalisme yang tidak mempersoalkan perbedaaan, tetapi mementingkan berbuat kebaikan (Jandra, 2005). Karena itu, kata-kata "kullin" dalam li kulli wijhatun ... (2: 148) dan li kullin ja'alna minkum syir'atan wa minhajan (5: 48) di atas sebagai "masing-masing umat beragama." Rasyid Ridha sebagaimana dikutip Jandra (2005) mengatakan, “...jadi, syari’ at yang berbeda-beda itu harus dipertimbangkan sebagai alasan untuk berlomba dalam amal saleh, dan bukan alasan untuk permusuhan dan persaingan dalam berbuat tidak baik." Bahkan dalam konteks teologis, Allah tidak melarang umat Islam melakukan aktivitas sosial dengan umat lain selama mereka tidak berbuat jahat.

Karenanya, dalam pandangan Al-Qur'an, pluralitas etnis, agama, dan budaya adalah keniscayaan yang merupakan kehendak dan desain Tuhan sendiri. Itulah kenapa kita hendaknya menerima kenyataan ini dengan positif, sebagaimana halnya kita menyaksikan fenomena keragaman yang terjadi pada dunia flora dan fauna (Hidayat, 2004). Semua itu merupakan fakta yang kehadirannya di luar kehendak kita.

\section{Pendidikan Multikultural}

Kesadaran terhadap masyarakat multikultural menjadi sebuah keniscayaan masyarakat global, mengingat keberadaan dunia yang semakin mengecil menimbulkan pergumulan masyarakat bermacam ragam kultur itu akan menjadi bagian dari hidup masyarakat saat ini dan ke depan. Bermunculannya konflik di masyarakat merupakan indikasi dimana kesadaran masyarakat terhadap multikultural ini sangat minim.Penelitian yang dilakukan Baldah, Sumawa dan Yuniarto (2016), Purnama (2017), Wirasari, Bain \& Atno (2018) menunjukan bahwa pendidikan multikultural berpengaruh siginifikan terhadap sikap pluralis dan 
moral kemasyarakatan (civic virtue). Sehingga pendidikan multikultural dirasa penting untuk dapat diimplementasikan dalam kehidupan sehari-hari demi mencegah terjadinya konflik di masyarakat.

Karenanya, pendidikan sebagai lembaga yang memiliki posisi strategis di masyarakat semestinya memberikan andil dalam proses penyandaran masyarakat terhadap isu-isu multikultural ini. Kenapa demikian? Sebab, Pendidikan merupakan salah satu kekuatan penggerak terjadinya perubahan pada suatu sistem sosial. Pendidikan menjadi tidak memiliki fungsi apa-apa ketika dia berlangsung dalam dunianya sendiri dengan tidak memperhatikan tingkat kebutuhan dan perkembangan yang terjadi di masyarakat.Secara mikro memang pendidikan berfungsi untuk memberikan kecerdasan dan wawasan kepada individu dan kelompok anak didiknya, tetapi dalam skala makri, dunia pendidikan merupakan institusi sosial yang berfungsi memberikan nilai-nilai tertentu dalam pendewasaan masyarakat menuju sistem sosial yang baru yang sesuai dengan arah perubahan zaman.

Karenanya, menurut Hidayat (2004)pendidikan dan kebudayaan sesungguhnya tidak dapat dipisahkan. Karena sejatinya merupakan salah satu tujuan yang hendak dicapai pendidikan adalah mengantarkan anak didik untuk bisa hidup di tengah dan bersama masyarakat guna memelihara dan mengembangkan nilai-nilai luhur budaya tempat mereka lahir dan tumbuh. Hal ini sejalan dengan tujuan pendidikan Islam yaitu:

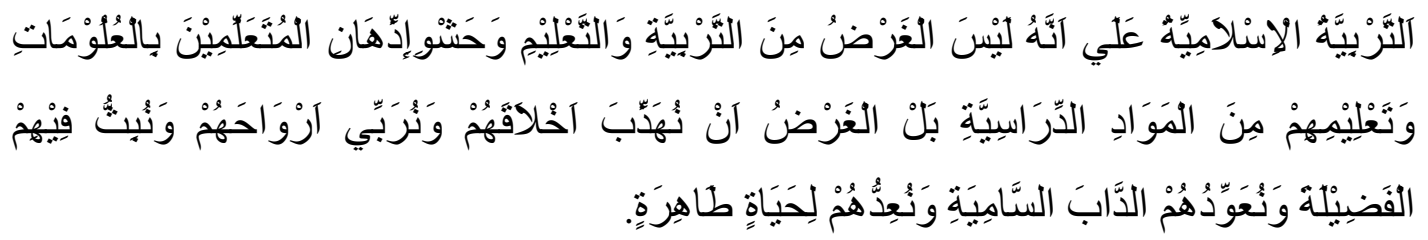

"Tujuan pendidikan Islam bukan sebatas mengisi pikiran siswa dengan ilmu pengetahuan dan materi pelajaran akan tetapi membersihkan jiwanya yang harus diisi dengan akhlak dan nilai-nilai yang baik dan dikondisikan supaya biasa menjalani hidup dengan baik."(al-Abrasyi, 1969).

Prinsip dalam pendidikan multikultural adalah menanamkan kesadaran akan pentingnya rasa persatuan dan kesatuan bangsa, dan mengembangkan kesadaran untuk dapat menghargai adanya kebhinnekaan, keberagaman dan kederajatan dalam 
masyarakat dan bernegara (Wihardit, 2010).Untuk itu, agar masyarakat dapat menghargai keragaman etnis, budaya dan agama, maka diperlukan beberapa syarat (Tabroni, 2007). Pertama, secara teologis filosofis dibutuhkan kesadaran dan keyakinan bahwa setiap individu dan etnis itu unik, namun dalam keunikannya masing-masing memiliki kebenaran dan kebaikan universal, hanya saja terbungkus dalam wadah budaya, bahasa, dan agama yang beragam dan bersifat lokal. Kedua, secara psikologis memerlukan pengondisian agar seseorang memiliki sifat inklusif dan positif terhadap orang lain yang berbeda. Ketiga, desain kurikulum pendidikan dan kultur sekolah harus dirancang sedemikian rupa sehingga anak didik mengalamai makna keragaman kultur.

Dengan demikian, multikultural tidak akan tumbuh jika tidak ditopang kualitas pendidikan yang baik. Sehingga masyarakat Indonesia yang tidak menemukan makna multikultural di sekolah, saat ini menjadi penting, sebab Era Industri 4.0 akan menuntut kesadaran masyarakat ke arah itu.

Sudah saatnya dunia pendidikan saat ini menjadi memacam miniatur dari sebuah keragaman budaya yang berkembang di masyarakat. Cara lain, selain bentuk kesadaran terhadap fakta zaman, juga sebagai bentuk perlawanan terhadap pemerintah yang sejak lama menjanjikan pendidikan sebagai alat pemuas nafsu duniawi dengan menyeragamkan kurikulum sekaligus menafikan keragaman budaya.

\section{Sejarah Singkat Pendidikan Multikultural}

Pendidikan multikultural telah lahir sekitar 42 tahun silam, yaitu setelah perang dunia II dengan lahirnya banyak negara dan berkembangnya prinsip-prinsip demokrasi. Dengan adanya gerakan kemerdekaan bukan hanya di bekas negara jajahan tetapi juga di negara-negara maju. Dari negara-negara bekas jajahan muncullah gerakan yang dapat kita sebut poskolonialisme yang melihat aib dari praktik-praktik kolonial yang membedakan harkat derajat manusia (Tabroni, 2007). Ada bangsa penjajah, bangsa super, dan bangsa dijajah atau didominasi bangsa lain.

Pakar pendidikan demokrasi di Amerika Serikat, John Dewey yang terkenal dengan pandangan progresivisme dalam bidang pendidikan menjadi masalah keanekaragaman di dalam masyarakat demokrasi sebagai salah satu masalah pokok pendidikan. Dan pendidikan multikultural telah menjadi topik diskusi maupun 
praktik pendidikan pada beberapa negara maju dengan mengambil tema utama pentingnya kebudayaan dalam praktik pendidikan untuk membangun suatu masyarakat demokratis.

Pendidikan multikulturalisme berkembang, bukan hanya di Amerika Serikat dewasa ini, akan tetapi juga di negara-negara Eropa. Perkembangan ini disebabkan perubahan wajah dunia yang sangat terbuka termasuk perubahan-perubahan profil kependudukan di muka bumi. Dunia tanpa batas yang ditopang dengan kemanjuan teknologi komunikasi menuntut suatu orientasi baru dalam pendidikan. Orientasi baru tersebut antara lain melihat praktik pendidikan sebagai bagian dari kegiatan kebudayaan global akan memberikan bentuk dan isi dan baru terhadap pendidikan multikultural.

Untuk itulah, pendidikan multikultural hadir sebagai wacana sekaligus praktik lintas batas. Dalam pendidikan multikultural terkait masalah-masalah keadilan (social justice), demokrasi, dan hak asasi manusia (Ruswandi, 2020). Para pakar pendidikan mengidentifikasi tiga lapis diskursus yang berkaitan dalam pendidikan multikultural. Pertama, masalah kebudayaan, dalam hal ini terkait masalah-masalah mengenai identitas budaya atau suatu kelompok masyarakat dan suku. Kedua, kebiasaan-kebiasaan, tradisi, pola-pola kelakuan yang hidup di tengah masyarakat. Ketiga, kegiatan atau kemajuan tertentu dari kelompok-kelompok masyarakat yang merupakan identitas yang melekat pada kelompok tertentu (Tabroni, 2007).

Selain itu, ada empat nilai inti atau core values dari pendidikan multikultural, yaitu: 1) apresiasi terhadap adanya kenyataan pluraritas budaya dalam masyarakat; 2) pengakuan terhadap harkat manusia dan hak asasi manusia; 3) pengembangan tanggung jawab masyarakat dunia; 4) pengembangan tanggung jawab manusia terhadap planet bumi (Tabroni, 2007). Berdasarkan nilai-nilai inti tersebut, maka dapat dirumuskan enam tujuan yang berkaitan dengan nilai-nilai inti pendidikan multikultural, yaitu: pertama, mengembangkan perspektif sejarah yang beragam dari kelompok-kelompok masyarakat. Kedua, memperkuat kesadaran budaya yang hidup di masyarakat. Ketiga, memperkuat kompetensi intelektual dari kebudayaankebudayaan yang hidup di masyarakat. Keempat, membasmi rasisme, seksisme, dan 
berbagai jenis prasangka. Kelima, mengembangkan kesadaran atas kepemilikan planet bumi, dan keenam, mengembangkan keterampilan aksi sosial.

\section{Strategi yang Dibutuhkan}

Lewat dunia pendidikan, masyarakat akan tercerahkan secara kultural. Masyarakat semakin terbuka dunianya dan semakin beragam. Masyarakat Jawa Barat, misalnya meskipun berada dalam lingkup yang tidak terlalu luas, namun dalam konteks global sesungguhnya mereka selalu berinteraksi dengan masyarakat yang berlainan kultur dan agama baik satu negara maupun berbeda negara.

Kehadiran muatan multikulturalisme di dunia pendidikan tiada lain untuk memberikan solusi atas sikap masyarakat, khususnya generasi mendatang dalam menghadapi keragaman di masyarakat. Dengan kesadaran multikultural masyarakat akan toleran dengan sendirinya, akan selalu menganggap kehadiran orang lain sebagai kemestian. Karenanya bagaimana kita dapat menghargai orang lain itu dengan menempatkan hak-haknya dan mensejajarkan dengan kita yang memiliki hak yang sama.

Fakta keragaman kultur di Jawa Barat bukan alasan untuk tumbuhnya sentimen, kebencian bahkan kekerasan. Dengan bekal pendidikan multikultural masyarakat Jawa Barat akan lebih bijak menghadapi perbedaan, dan menjadikan perbedaan itu sebagai sebuah kekuatan untuk membangun peradaban di tatar Sunda.

Yang mungkin masih menjadi persoalan adalah sejauh mana kesadaran pemerintah daerah atau instansi-instansi terkait menganggap pentingnya memasukkan muatan multikulturalisme ini ke dalam dunia pendidikan. Untuk itu diperlukan adanya strategi dan langkah konkret agar pendidikan multikutural ini dapat dilakukan, yaitu pertama, brainstorming (tukar gagasan) terbuka yang melibatkan berbagai kalangan untuk membedah mengapa pendidikan multikultural ini penting, dan bagaimana pula menerapkannya hingga media apa yang perlu dilibatkan.Hal ini penting untuk dilakukan karena kegiatan brainstorming dapat membiasakan dan menumbuhkan dialog interaktif. Dialog yang demikian diharapkan dapat mengikis terjadinya konflik apalagi di lingkungan masyarakat yang plural. Junaidi (2018) mengatakan bahwa minimnya kesadaran berdialog dengan berbagai agama, etnis, dan budaya menyebabkan pendidikan menjadi 
sangat ekslusif dan tidak toleran.Secara lebih khusus, interpretasi doktrin agama dianggap sebagai pemicu lahirnya sejumlah konflik horizontal (Baidi, 2010). Padahal agama di masa depan adalah agama yang mampu hidup di lingkungan masyarakat dunia (Coward, 1994). Sementara itu, faktor yang menyebabkan terjadinya konflik di masyarakat adalah kurangnya pemahaman mengenai konsep multikultural yang ada dan hidup serta berkembang sejak lama (Setiawan\& Amal, 2016), faktor keluarga, minimnya pendidikan orang tua, dan perkembangan teknologi serta media massa (Selvia \& Nurizzati, 2017; Nalle 2017). Oleh karena itu, praktek brainstorming dapat menjadi salah satu solusi penguatan pemahaman konsep multikultural dan mengisi kekosongan puzzle pendidikan pada diri seseorang, sehingga diharapkan brainstoriming dapat meminimalisir terjadinya konflik dan menumbulkan sikap pluralisme di kalangan sesama.

Kedua, perlu disusun sejumlah kegiatan baik yang bersifat wacana (seperti seminar, lokakarya, dan talk show), maupun yang bersifat praktis (seperti riset, penyusunan modul, penyusunan kurikulum baru, pembuatan buku, pelatihanpelatihan, simulasi, kampanye media dan lainnya). Kegiatan yang bersifat wacana akan menghilangkan pandangan yang menganggap bahwa kelompok yang satu lebih unggul daripada kelompok yang lain. Sehingga sikap elagiter dan nilai kemanusiaan akan berkembang di dunia pendidikan. Sementara itu kegiatan yang bersifat praktis dipercaya dapat menanamkan pemahaman dan penghargaan terhadap keragaman kultur, etnis, agama, ras, dan pandangan hidup. Pemahamandan penghargaan atas keberagaman tersebut dapat diwujudkan di lembaga pendidikan ataupun di luar lembaga pendidikan, baik secara formal, informal maupun nonformal. Pada ruang lingkup yang lebih sempit, yakni kurikulum, pendidikan multikultural dapat diterapkan dalam pembelajaran di semua mata pelajaran. Dalam hal ini pendidikan multikultural seharusnya diintegrasikan dengan dengan mata pelajaran yang diampu oleh pendidik, karena secara eksplisit pendidikan multikultural sejatinya telah disediakan dalam kompetensi inti kurikulum 2013 (Wirasari, Bain dan Atno, 2018). Sementara itu, pendidik dan tenaga pendidik harus memiliki pengetahuan dan memahami nilai-nilai kebudayaan bangsa Indonesia yang diimplementasikan pada ranah kognitif, afektif serta psikomototik (Supriatin, 2017). Sebuah penelitian mengatakan bahwa pendidik 
memiliki peran penting dalam membangun karakter peserta didik sebagai bagian yang tidak terpisahkan dari pendidikan multikultural (Rahmawati dan Suniti, 2017). Oleh karenanya, kebijakan di lembaga pendidikan harus difokuskan pada penanaman sikap multikulturalisme,sebab kebijakan di lembaga pendidikan yang menghambat toleransi, termasuk penghinaan ras, etnis, dan jenis kelamin merupakan aspek yang menghambat pelaksanaan pendidikan multikultural (Suharsono, 2017). Sehingga sejalan dengan amanat Suryana (2015) yang mengatakan bahwa lembaga pendidikan memegang peranan penting dalam tercapainya tujuan pendidikan nasional berbasis multikulturalisme.

Dengan strategi yang demikian diharapkan dapat terwujudnya pendidikan multikultural di Jawa Barat yang relevan dengan kultur budaya Sunda yang selain taat dalam beragama tetapi juga memiliki sifat yang ramah terhadap sesama mnusia, siapa pun dan dari mana pun asalnya.

\section{KESIMPULAN}

Kesadaran terhadap masyarakat multikultural menjadi sebuah keniscayaan masyarakat global, mengingat keberadaan dunia yang semakin mengecil menimbulkan pergumulan masyarakat bermacam ragam kultur itu akan menjadi bagian dari hidup masyarakat saat ini dan ke depan. Agar tidak menjadi konflik horizintal maka diperlukan adanya strategi yang harus dilakukan. Strategi yang ditawarkan adalah brainstorming, dan penyusunan sejumlah kegiatan yang bersifat wacana dan praktis.

\section{REFERENSI}

Al-Abrasyi,A. 1969.At-Tarbiyyah al-Islamiyyah wa Falsafatuha. Beirut: Dar al-Fikr.

Baidhawi, Z. 2002. Ambivalensi Agama, Konflik dan Nirkekerasan. Yogyakarta: Lesfi.

Baidi. 2010. Agama dan Multikulturalisme: Pengembangan Kerukunan Masyarakat Melalui Pendekatan Agama, Millah: Jurnal Studi Agama, Edisi Khusus Desember 2010 Studi Islam dalam Multiperspektif, 1-29. https://doi.org/10.20885/millah.ed.khus.art1.

Baldah, W., Sumarna, C., dan Yuniarto, B. 2016. Pengaruh Nilai-nilai Multikultural terhadap Pembentukan Sikap Pluralis Siswa di MTsN Babakan Ciwaringin Kabupaten Cirebon, Edueksos: Jurnal Pendidikan Sosial dan Ekonomi,5(1), 115-126. https://doi.org/10.24235/edueksos.v5i1.1117. 
Coward, H. 1994. Pluralisme:Tantangan bagi Agama-Agama. Yogyyakarta: Penerbit Kanisius.

Data Rumah Ibadah. 2019. https://jabar.kemenag.go.id/portal/data/data-rumahibadah. Diakses 21 Maret 2020.

Effendi,J. 2004. Kemusliman dan Kemajemukan Agama. Yogyakarta: Pustaka Pelajar.

Hidayat, K. 2004. Merawat Keragaman Budaya. Dalam Pendidikan Manusia Indonesia. Jakarta: Kompas.

Ibrahim, R. 2013. Pendidikan Multikultural: Pengertian, Prinsip, dan Relevansinya dengan Tujuan Pendidikan Islam, Addin: Media Dialektika Ilmu Islam, 7(1), 129-154.https://doi.org/10.21043/addin.v7i1.573.

Jandra, M. 2005. Pluralisme Agama dan Multikulturalisme.Dalam Reivensi Islam Multikultural. Surabaya: PSB-PS UMS.

Jumlah Wisatawan Bulanan yang Datang ke Jawa Barat. 2017. https://jabar.bps.go.id/dynamictable/2020/02/04/206/jumlah-wisatawanmancanegara-bulanan-yang-datang-ke-jawa-barat-2017.html.

Jumlah Wisatawan Bulanan yang Datang ke Jawa Barat. 2018. https://jabar.bps.go.id/dynamictable/2020/02/04/207/jumlah-wisatawanmancanegara-bulanan-yang-datang-ke-jawa-barat-2018.html.

Jumlah Wisatawan Bulanan yang Datang ke Jawa Barat. 2019. https://jabar.bps.go.id/dynamictable/2020/02/04/208/jumlah-wisatawanmancanegara-bulanan-yang-datang-ke-jawa-barat-2019.html.

Jumlah Wisatawan Mancanegaran Bulanan yang Datang ke Jawa Barat. 2016. https://jabar.bps.go.id/dynamictable/2020/02/04/205/jumlah-wisatawanmancanegara-bulanan-yang-datang-ke-jawa-barat-2016.html.

Junaidi. 2018. Model Pendidikan Multikultural. Al-Insyiroh: Jurnal Studi Keislaman, 2(1), 57-72. https://doi.org/10.35309/alinsyiroh.v2i1.3332.

Nalle, E.S. 2017. Peran Orang Tua, Sekolah dan Masyarakat dalam Membangun Kewargaan (Civil Society) di SMA Negeri 4 Kupang. Edueksos: Jurnal Pendidikan Sosial dan Ekonomi,6(2), 101-120. https://doi.org/10.24235/edueksos.v6i2.2189.

Penduduk Menurut Kelompok Umur dan Status Kewarganegaraan. 2010. https://sp2010.bps.go.id/index.php/site/tabel?tid=322\&wid=3200000000.

Piliang, Y. A. 2004. Dunia yang Dilipat. Bandung: Jalasutra.

Rahmawati, T., \& Suniti. 2017. Peran Guru Ilmu Pengetahun Sosial dalam Membangun Karakter Demokratis Peserta Didik Kelas IX di SMP Negeri 1 Gempol Kabupaten Cirebon, Edueksos: Jurnal Pendidikan Sosial dan Ekonomi,6(2), 149-164. https://doi.org/10.24235/edueksos.v6i2.3159. 
Ruastati, N. M. 2010. Multikulturalisme dan Pariwisata Bali, Mudra: Jurnal Seni Budaya, 25(2), 108-119.

Ruswandi, U. 2020. Catatan Kuliah Isu-isu Pendidikan Global. Tidak Diterbitkan.

Selvia \& Nurizzati, Y. 2017. Upaya Guru dalam Menyikapi Pergeseran Perilaku Siswa dalam Perspektif Nilai-Nilai Budaya Bangsa di SMP Negeri 18 Kota Cirebon. Edueksos: Jurnal Pendidikan Sosial dan Ekonomi,6(2), 165-178. https://doi.org/10.24235/edueksos.v6i2.3170.

Setiawan, D., \& Amal, B. 2016.Membangun Pemahaman Multikultural dan Multiagama Guna Menangkal Radikalisme di Aceh Singkil.Al-Ulum, 16(2), 348-367. https://jurnal.iaingorontalo.ac.id/index.php/au/article/view/155.

Shilmy, P. 2017. Pengaruh Pendidikan Multikultural terhadap Pengembangan Civic Virtue Siswa SMP Dan SMA di Sekolah Indonesia Singapura (Tesis, Universitas Pendidikan Indonesia). http://repository.upi.edu/32049/.

Suharsono, S. 2017. Pendidikan Multikultural. Edusiana: Jurnal Manajemen dan Pendidikan Islam, 4(1), 13-23. https://doi.org/10.30957/edusiana.v4i1.3.

Supriatin, A., \& Nasution, A. R. (2017).Implementasi Pendidikan Multikultural dalam Praktik Pendidikan di Indonesia.Elementary: Jurnal Ilmiah Pendidikan Dasar, 3(1), 1-13. https://doi.org/10.32332/elementary.v3i1.785.

Tabroni, R. 2007. Transformasi Sosial Berbasis Kearifan Lokal dalam Konteks Masyarakat Jawa Barat yang Multikultural. Bandung: Sekretariat Daerah Provinsi Jawa Barat.

Tingkat Penghunian Kamar Hotel Jawa Barat Desember 2019. 2019. https://jabar.bps.go.id/pressrelease/2020/02/03/770/tingkat-penghuniankamar-hotel--jawa-barat-desember-2019-sebesar-54-82-persen.html.

Tingkat Penghunian Kamar Hotel Jawa Barat Desember 2020. 2020. https://jabar.bps.go.id/pressrelease/2020/03/02/794/tingkat-penghuniankamar-hotel-di-jawa-barat-januari-2020-sebesar-45-96-persen.html.

Wirasari, W., Bain, B., \& Atno, A..2018. Pengaruh Pelaksanaan Pendidikan Multikultural pada Mata Pelajaran Sejarah terhadap Sikap Pluralis Siswa Kelas XI SMA Negeri 2 Pekalongan Tahun Pelajaran 2017/2018.Indonesian Journal of History Education, 6(1), 76-88. 